\title{
A Glycoprotein Mutation That Emerged during the 2013-2016 Ebola Virus Epidemic Alters Proteolysis and Accelerates Membrane Fusion
}

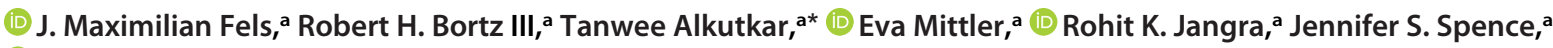 \\ (D) Kartik Chandran ${ }^{a}$
}

aDepartment of Microbiology and Immunology, Albert Einstein College of Medicine, Bronx, New York, USA

\begin{abstract}
Genomic surveillance of viral isolates during the 2013-2016 Ebola virus epidemic in Western Africa, the largest and most devastating filovirus outbreak on record, revealed several novel mutations. The responsible strain, named Makona, carries an A-to-V substitution at position 82 (A82V) in the glycoprotein (GP), which is associated with enhanced infectivity in vitro. Here, we investigated the mechanistic basis for this enhancement as well as the interplay between A82V and a T-to-I substitution at residue 544 of GP, which also modulates infectivity in cell culture. We found that both $82 \mathrm{~V}$ and $544 \mathrm{I}$ destabilize GP, with the residue at position 544 impacting overall stability, while $82 \mathrm{~V}$ specifically destabilizes proteolytically cleaved GP. Both residues also promote faster kinetics of lipid mixing of the viral and host membranes in live cells, individually and in tandem, which correlates with faster times to fusion following colocalization with the viral receptor Niemann-Pick C1 (NPC1). Furthermore, GPs bearing $82 \mathrm{~V}$ are more sensitive to proteolysis by cathepsin $\mathrm{L}$ (CatL), a key host factor for viral entry. Intriguingly, CatL processed $82 \mathrm{~V}$ variant GPs to a novel product with a molecular weight of approximately 12,000 (12K), which we hypothesize corresponds to a form of GP that is pre-triggered for fusion. We thus propose a model in which $82 \mathrm{~V}$ promotes more efficient GP processing by CatL, leading to faster viral fusion kinetics and higher levels of infectivity.
\end{abstract}

IMPORTANCE The 2013-2016 outbreak of Ebola virus disease in West Africa demonstrated the potential for previously localized outbreaks to turn into regional, or even global, health emergencies. With over 28,000 cases and 11,000 confirmed deaths, this outbreak was over 50 times as large as any previously recorded. This outbreak also afforded the largest-ever collection of Ebola virus genomic sequence data, allowing new insights into viral transmission and evolution. Viral mutants arising during the outbreak have attracted attention for their potentially altered patterns of infectivity in cell culture, with potential, if unclear, implications for increased viral spread and/or virulence. Here, we report the properties of one such mutation in the viral glycoprotein, A82V, and its interplay with a previously described polymorphism at position 544 . We show that mutations at both residues promote infection and fusion activation in cells but that A82V additionally leads to increased infectivity under cathepsin-limited conditions and the generation of a novel glycoprotein cleavage product.

KEYWORDS Ebola virus, proteolysis, variant surface glycoprotein

- bola virus (EBOV), a member of the viral family Filoviridae, was responsible for the - largest recorded outbreak of filovirus disease in history, in Western Africa from 2013 to 2016. This epidemic is associated with over 28,000 suspected or confirmed cases and caused over 11,000 deaths. Genomic surveillance of viral isolates from infected patients has yielded a wealth of information on how the virus spread and
Citation Fels JM, Bortz RH, III, Alkutkar T, Mittler E, Jangra RK, Spence JS, Chandran K. 2021. A glycoprotein mutation that emerged during the 2013-2016 Ebola virus epidemic alters proteolysis and accelerates membrane fusion. mBio 12:e03616-20. https://doi.org/10.1128/ mBio.03616-20

Editor Stacy M. Horner, Duke University Medical Center

Copyright $\odot 2021$ Fels et al. This is an openaccess article distributed under the terms of the Creative Commons Attribution 4.0 International license.

Address correspondence to Jennifer S. Spence, jspence008@gmail.com, or Kartik Chandran, kartik.chandran@einsteinmed.org.

* Present address: Tanwee Alkutkar Department of Integrative Structural and Computational Biology, The Scripps Research Institute, La Jolla, California, USA.

Received 21 December 2020

Accepted 4 January 2021

Published 16 February 2021 
evolved during the epidemic. The index case is thought to be a 4-year-old boy in Guinea, who may have been exposed to EBOV as a result of contact with an infected bat. The virus then spread to neighboring Liberia and Sierra Leone in 2014 exclusively through human-to-human transmission (1-4). The EBOV strain responsible for this outbreak was named Makona (5) and is genetically distinct from the Mayinga isolate from the first recorded EBOV outbreak (in the Democratic Republic of Congo in 1976).

Three missense mutations in the EBOV Makona genome sequence, (i) an R-to-C mutation at position 111 (R111C) in the nucleoprotein (NP), (ii) D759G in the polymerase (L), and (iii) A82V in the viral glycoprotein (GP) [GP(A82V)], arose early in the epidemic and came to dominate the viral isolates collected during the last half of 2014 and onward (6). The A82V mutation in particular was proposed to be an adaptation arising during the prolonged chain of human-to-human transmission. This is supported by the observed increase in infection of primate cells and the corollary decrease in infection of bat cell lines for viruses carrying $\operatorname{GP}(A 82 \mathrm{~V})(7,8)$. Although this observation has not been recapitulated in animal models of infection, including mice and rhesus macaques (9), there is mechanistic evidence that the A82V mutation impacts viral entry (10). The entry of EBOV depends on several host factors, including the obligate intracellular filovirus receptor Niemann-Pick C1 (NPC1) $(11,12)$ as well as cysteine cathepsin proteases that cleave GP to reveal the receptor-binding site (RBS) $(13,14)$. It remains unknown if the A82V mutation promotes more efficient usage of any of these known host factors or if it allows the virus to coopt novel host factors in order to mediate entry.

Another polymorphism in EBOV GP, at position 544, has also been shown to influence viral entry in tissue culture, with 544 l conferring enhanced infectivity relative to 544T (15-18). Because Makona isolates have 544T, while Mayinga isolates have 544l, we postulated that the A $82 \mathrm{~V}$ mutation in Makona arose, at least in part, as an infection-promoting response to the presence of 544T. Additional differences between Mayinga GP [GP(Mayinga)] and Makona GP, such as A503V and a number of substitutions in the mucin domain, have previously been ruled out as explanations for the increased infectivity of Makona isolates bearing $82 \mathrm{~V}$ (10).

Here, we set out to investigate the interplay between polymorphisms at positions 82 and 544 in the background of GP(Makona) and GP(Mayinga). We found that both $82 \mathrm{~V}$ and $544 \mathrm{I}$ mutations accelerated the kinetics of viral membrane fusion in an additive manner. Furthermore, $82 \mathrm{~V}$ variants were more susceptible to proteolysis by the endosomal cysteine protease cathepsin $\mathrm{L}$ (CatL) and displayed a striking alteration in the pattern of GP proteolytic cleavage, which correlated with enhanced viral entry under cathepsin-limited conditions. Taken together, our findings reveal a potential mechanism by which the A82V mutation enhances EBOV GP-dependent viral entry and infection.

\section{RESULTS}

GP variants recapitulate previously reported infection and receptor binding phenotypes. We generated four GP variants, Makona 82A/544T, Makona 82V/544T, Mayinga 82A/544I, and Mayinga 82V/544I [here referred to as GP(Mak 82A/544T), GP (Mak 82V/544T), GP(May 82A/544I), and GP(May 82V/544I), respectively, in order to highlight the residues investigated], as vesicular stomatitis virus (VSV) pseudotypes (VSV-GP). Since none of the mutations of interest are in the GP mucin domain, and the mucin domain is dispensable for infection in cell culture $(14,19)$, all pseudotypes generated have a deletion of amino acid residues 309 to 489 in GP.

In order to validate these pseudotyped viruses, we first measured their infectivity in Vero cells. The A82V and T544I mutations, both alone and together, promoted higher levels of infectivity (Fig. 1A), as previously reported (15-18). The differences in infectivity did not stem from differences in GP density on the viral surface, as all four variants demonstrated comparable levels of GP incorporation into particles (Fig. 1B).

The various infectivity phenotypes of the mutants also could not be readily explained by differences in receptor interaction. Due to the proximity of position 82 to the RBS of GP, it has been speculated that the A82V mutation could promote binding 

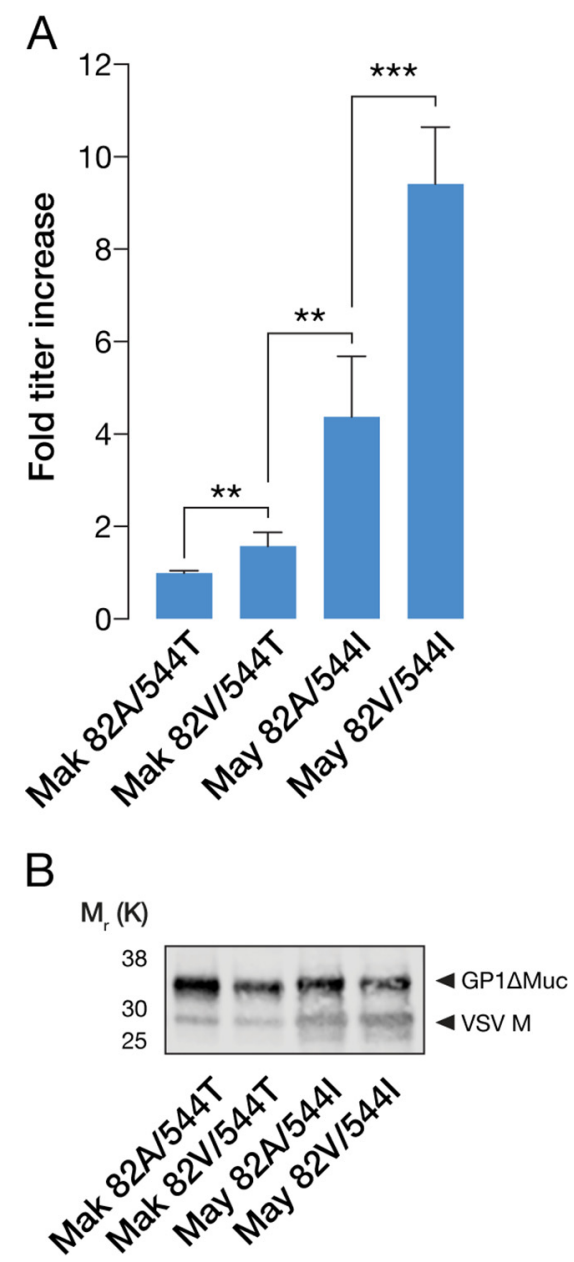

FIG 1 (A) Mean fold increases in viral titers ( \pm SD) of GP variants compared to GP(Mak 82A/544T). $82 \mathrm{~V}, 544 \mathrm{l}$, or both in tandem significantly increase titers $\left({ }^{* *}, P<0.002 ;{ }^{* * *}, P<0.001\right.$ [by unpaired two-tailed $t$ tests]) ( $n=6$, from three independent experiments). (B) Representative Western blot of VSV M and EBOV GP indicating similar levels of GP incorporation into VSV for all four GP variants.

to the critical endo/lysosomal filovirus receptor Niemann-Pick C1 (NPC1) $(7,11,12,20)$. Following pretreatment of the VSV-GPs with thermolysin (THL), which mimics the activity of cathepsin B (CatB) (14), we used an enzyme-linked immunosorbent assay (ELISA) to measure NPC1 binding to cleaved $G P\left(\mathrm{GP}_{\mathrm{CL}}\right)(21)$. As reported previously (10), the A82V mutation did not affect $\mathrm{GP}_{\mathrm{CL}}-\mathrm{NPC1}$ binding (Fig. 2).

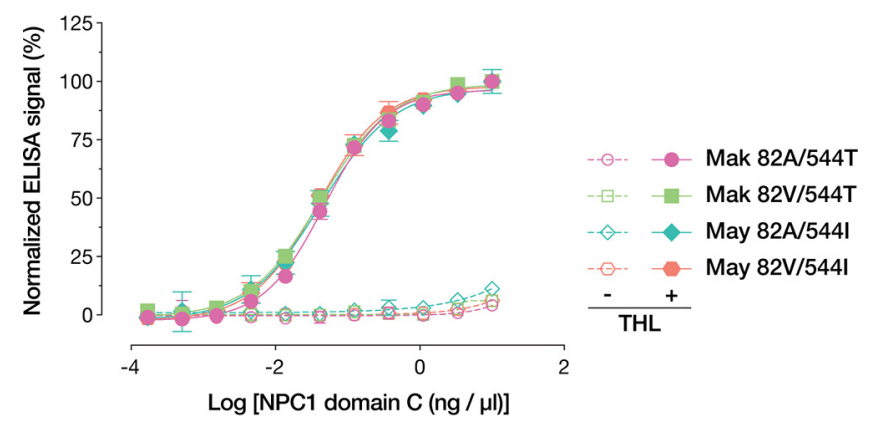

FIG 2 Normalized amounts of VSV-GP variants, in the native or THL-cleaved state, were captured onto ELISA plates using KZ52. Once cleaved, all four GP variants are able to bind NPC1 domain C at equal levels. Means $( \pm S D)$ of results from two independent experiments with three technical replicates are shown $(n=6)$. 


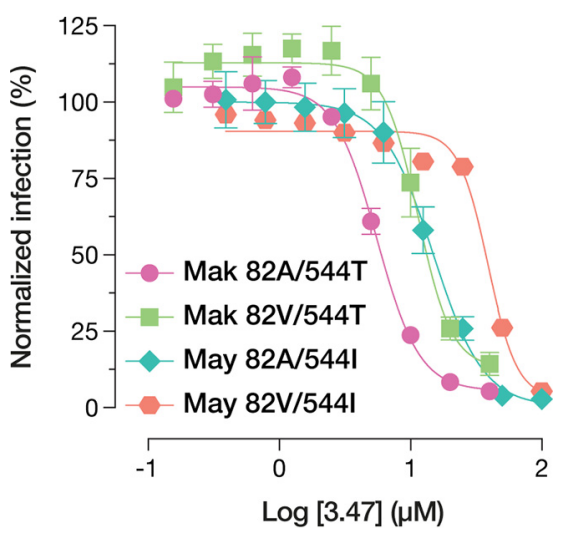

FIG 3 Normalized infectivity levels at various concentrations of the viral inhibitor 3.47. Means ( \pm SD) of results from two independent experiments with three technical replicates are shown $(n=6)$. At 3.47 concentrations of $>2.5$ and $>12.5 \mu \mathrm{M}$, respectively, Makona and Mayinga VSV-GP variants bearing $82 \mathrm{~V}$ are significantly more infectious than their 82A counterparts $(P<0.001$ [by multiple $t$ tests with the Holm-Šídák correction for multiple testing]).

One of the most striking and widely reported phenotypes associated with the A82V mutation is increased resistance to the small-molecule viral inhibitor 3.47, which targets the GP-NPC1 interaction $(12,22,23)$. We observed that the polymorphisms at positions 82 and 544 made independent and additive contributions to viral sensitivity to 3.47. Specifically, A82V and T544I were each associated with increased 3.47 resistance, with the $82 \mathrm{~A} / 544 \mathrm{~T}$ and $82 \mathrm{~V} / 544 \mathrm{I}$ genotypes conferring low and high levels of resistance, respectively, and the mixed $82 \mathrm{~V} / 544 \mathrm{~T}$ and $82 \mathrm{~A} / 544 \mathrm{I}$ genotypes conferring intermediate levels of resistance (Fig. 3). These results are largely in line with previously reported data (10) and indicate that both $\mathrm{A} 82 \mathrm{~V}$ and $\mathrm{T} 544 \mathrm{I}$ promote viral resistance to 3.47 in a manner likely unrelated to the GP-NPC1 interaction.

The GP-destabilizing effect of the A82V mutation is unmasked by proteolysis. Single point mutations have previously been shown to have dramatic effects on GP stability, with associated impacts on viral infectivity (24). A previous report implicated the reduced stability of the $\mathrm{A} 82 \mathrm{~V}$ mutant as the basis for its increased infectivity in vitro and in vivo (10). Likewise, proteolysis has a destabilizing effect on GP that is thought to promote fusion activation (24-26). Accordingly, we set out to investigate the stability of GP mutants in both uncleaved and precleaved states using an ELISA that measures the thermostability of an epitope spanning GP1 and GP2 (26). By measuring the halfmaximal melting temperature $\left(T_{m}\right)$ of GPs, we found that uncleaved GPs bearing $544 \mathrm{I}$ were significantly less stable than their 544T counterparts (Fig. 4A and C). Upon THL cleavage, all GPs were destabilized, with $T_{m}$ values decreasing $5^{\circ} \mathrm{C}$ to $6^{\circ} \mathrm{C}$ compared to their uncleaved counterparts. Furthermore, THL cleavage unmasked more nuanced differences in stability, with GPs bearing $82 \mathrm{~V}$ being significantly destabilized compared to the $82 \mathrm{~A}$ variants (Fig. 4B and D). Thus, the polymorphisms at both positions 82 and 544 appear to regulate GP stability but may do so at different steps in entry: either upstream (position 544) or downstream (positions 82) of the proteolytic cleavage mimicked by THL.

A82V and T544I increase the rate of GP fusion activation but not its probability. In order to investigate the impact of these GP mutations on fusogenic activation, we used a fluorescence dequenching assay to observe viral fusion triggering within live cells on a single-particle basis $(27,28)$. Membranes of purified viruses were labeled with self-quenching concentrations of the lipophilic dye 1,1'-dioctadecyl-3,3,3',3'-tetramethylindodicarbocyanine (DiD). Mixing of lipids between the host and viral membranes as a result of hemifusion or full fusion enables the dequenching of the dye and a sharp increase in fluorescence intensity. We observed that the polymorphisms at positions 82 and 544 made independent and additive contributions to the kinetics of fluorescence dequenching (Fig. 5A). Specifically, VSV-GP(May 82V/544I) exhibited the 


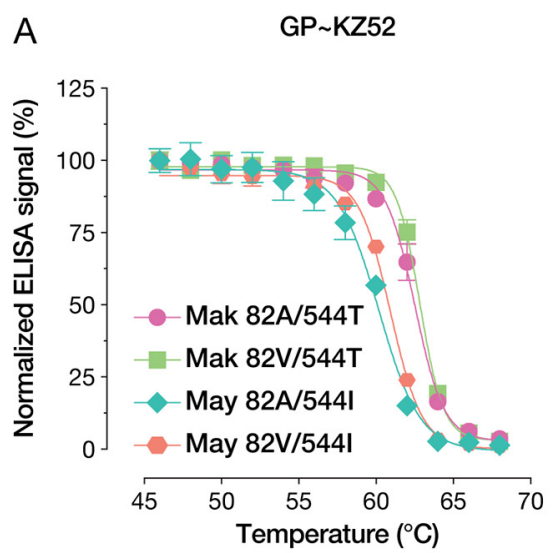
B
GP+THL KZ52

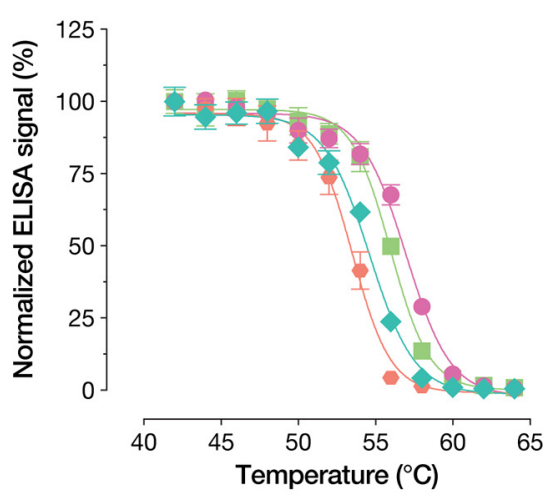

C

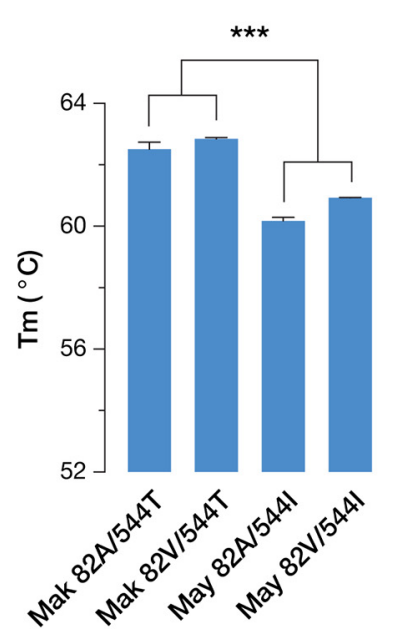

$\mathrm{D}$

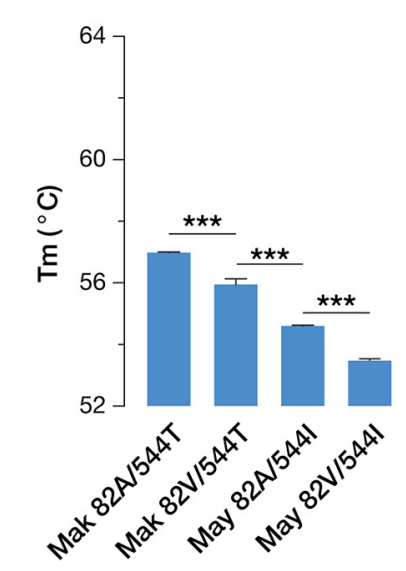

FIG 4 (A) Normalized ELISA signal of KZ52 binding to native VSV-GP variants following heating. Means $( \pm S D)$ of results from two independent experiments with three technical replicates $(n=6)$ are shown. (B) Normalized ELISA signal of KZ52 binding to THL-cleaved VSV-GP variants following heating. Means $( \pm S D)$ of results from two independent experiments with three technical replicates $(n=6)$ are shown. (C) $T_{m}$ values for native VSV-GP variants, derived by nonlinear regression analysis of ELISA signals. Statistical significance was determined by one-way ANOVA with Tukey correction for multiple testing $\left({ }^{*}, P<0.033 ;{ }^{* *}, P<0.002 ;{ }^{* * *}, P<0.001\right)$ (D) $T_{m}$ values for THL-cleaved VSV-GP variants, derived by nonlinear regression analysis of ELISA signals. Statistical significance was determined by one-way ANOVA with Tukey correction for multiple testing $\left({ }^{*}, P<0.033 ;{ }^{* *}, P<0.002 ;{ }^{* * *}, P<\right.$ $0.001)$.

fastest kinetics of lipid mixing, with a $t_{1 / 2}$ (time needed for $50 \%$ of particles to dequench) of $24 \mathrm{~min}$, whereas VSV-GP(Mak $82 \mathrm{~A} / 544 \mathrm{~T})$ exhibited the slowest $\left(t_{1 / 2}=\right.$ $57 \mathrm{~min})$. Viruses with the mixed GP genotypes exhibited intermediate kinetics of lipid mixing $\left(t_{1 / 2}=44\right.$ and $47 \mathrm{~min}$ for $82 \mathrm{~A} / 544 \mathrm{I}$ and $82 \mathrm{~V} / 544 \mathrm{~T}$, respectively). Interestingly, the lipid mixing kinetics of these viruses in cells were concordant with their respective susceptibilities to inhibition by 3.47 (Fig. 3).

However, despite these differences in the kinetics of GP-dependent lipid mixing in cells, we observed no difference with respect to the total percentages of cell-associated particles eventually inducing lipid mixing (Fig. 5D). Since this assay is unable to differentiate hemifusion from the formation of fusion pores and viral content release into the cytoplasm, this suggests that the differences in infectivity observed for the position 82 and 544 mutants arise at a very late step in fusion activation that we were unable to resolve other than as a change in the kinetics of fusion activation. It is also unknown how the timing of fusion impacts the probability of establishing productive infection, adding a layer of complexity to inferences about the relationship between lipid mixing and infectivity. 
A

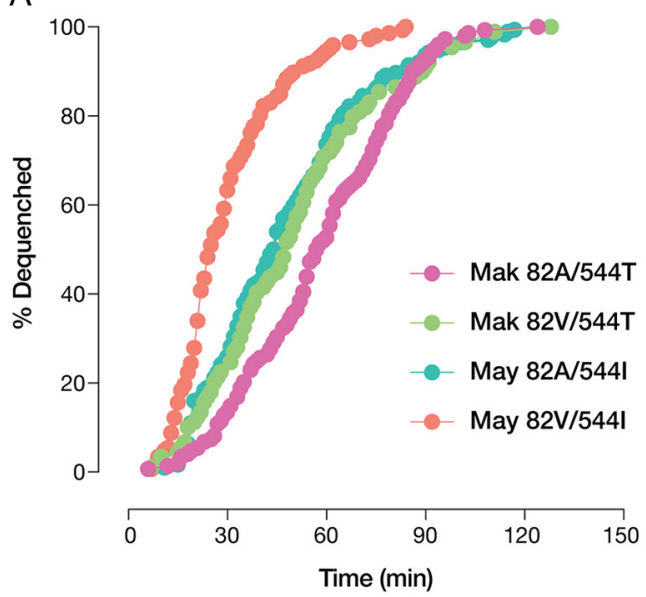

$\mathrm{B}$

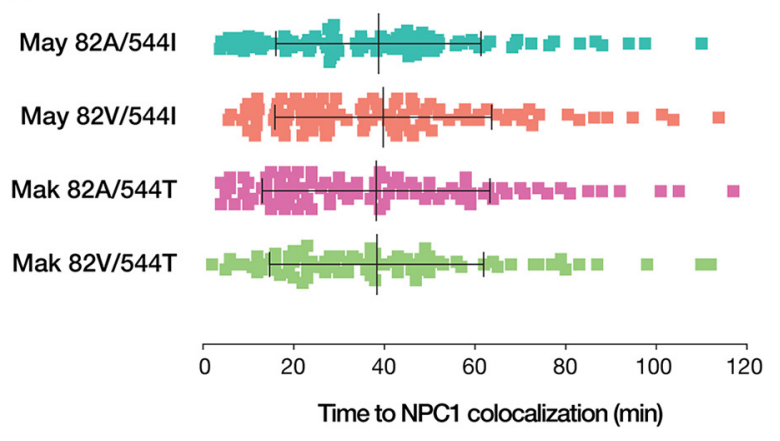

C

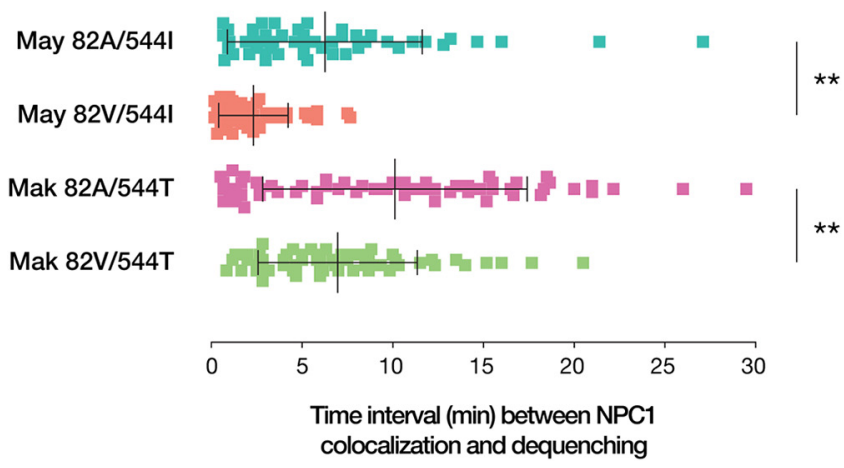

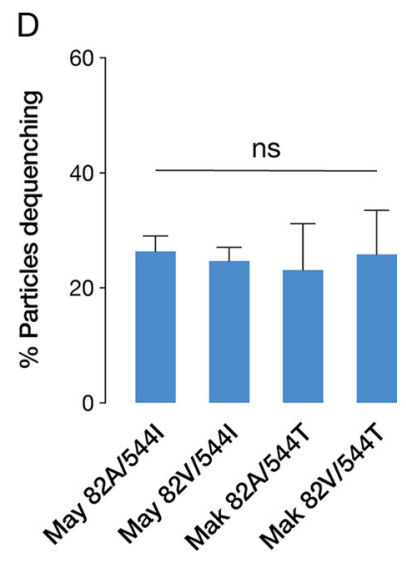

E

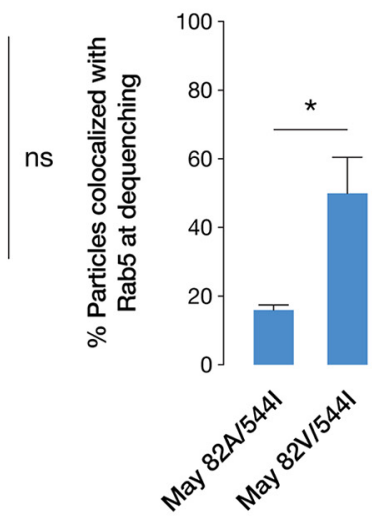

FIG 5 (A) Kinetics of viral fusion triggering. (B) Time of viral colocalization with NPC1. Data represent the means and SD from three independent experiments. ns, not significant. (C) Time interval between viral colocalization with NPC1 and the onset of lipid mixing. Data represent the means and SD from three independent experiments (**, $P<0.01$ [by one-way ANOVA with a post hoc Tukey test]). (D) Total percentage of virions undergoing GP-mediated lipid mixing. Data represent the means and SD from three independent experiments. (E) Total percentage of virions colocalized with Rab5 at the time of lipid mixing ( ${ }^{*}, P<0.05$ [by Student's $t$ test]). Data represent the means and SD from three independent experiments.

We also observed no significant differences among the mutants in terms of the mean time of colocalization with NPC1, demonstrating that internalization and trafficking are unaltered (Fig. 5B). However, once delivered to NPC1-positive compartments, VSV-GP(May 82V/544I) exhibited a shorter mean lag to lipid mixing ( $2.3 \mathrm{~min}$ ) than GP (May 82A/544I) (6.3 min) (Fig. 5C). The lag increased slightly with GP(Mak 82V/544T) (6.9 min) and to a greater extent with GP(Mak 82A/544T) (10.1 min). 
Because the dramatically accelerated fusion kinetics of GP(May 82V/544I) indicated that its threshold for triggering may be significantly reduced, we examined lipid mixing in Rab5-positive compartments (Fig. 5E). The percentage of virions undergoing dequenching in intermediate endosomes, as differentiated from early endosomes by the presence of NPC1 at the time of fusion, was significantly higher with this mutant than with GP(May 82A/544I), demonstrating that more particles can be triggered to fuse in less-mature endocytic vesicles.

$82 \mathrm{~V}$ variants have greater relative infectivity in CatL-deficient cells. To account for the differing fusion kinetics observed among the GP variants, we next examined GP proteolytic susceptibility in vitro. Previous findings indicate that both the $A 82 \mathrm{~V}$ and T544I mutations influence the CatB dependence of viral entry. While T544I alone does not promote resistance to the CatB inhibitor CA074, the residue at position 544 influences the overall dependence on CatB $(10,18)$. Here, we found that only the $82 \mathrm{~V} / 544 \mathrm{I}$ variant was resistant to CA074 (Fig. 6A), largely consistent with Wang and coworkers' observations. Because CatL can support EBOV GP-dependent entry (13, 14, 29), we next sought to investigate the effect of the position $82 / 544$ polymorphisms on viral entry under CatL-limited conditions. To overcome the challenges associated with selective inhibition of CatL in cells with irreversible activity-based inhibitors, we previously generated U2OS CatL knockout (KO) cells through CRISPR/Cas9 genome engineering (23). We then tested the kinetics of lipid mixing of the GP Mayinga variants that displayed the greatest difference on wild-type (WT) U2OS cells. To our surprise, we found that knocking out CatL drastically slowed the fusion kinetics of VSV-GP(May 82V/544I) but had a comparatively small effect on VSV-GP(May 82A/544I) (Fig. 6B). Both 82V variants afforded higher levels of infectivity than their 82A counterparts in CatL KO cells even after adjusting for their relative infectivities in the control cells (Fig. 6C). Taken together, our results suggest that $\mathrm{A} 82 \mathrm{~V}$ and $\mathrm{T} 544 \mathrm{I}$ are required to bypass the entry requirement for $C a t B$ and that $A 82 V$ drives faster fusion kinetics through a CatL-dependent mechanism. Furthermore, the relatively higher levels of infectivity of $82 \mathrm{~V}$ variants in CatL KO cells indicate that they are also able to utilize non-CatL cathepsins more efficiently in order to drive viral entry.

A82V mutations allow GP to be processed to a novel cleavage product by CatL. To explore the molecular basis of enhanced viral entry in CatL-deficient cells afforded by the A82V mutation, we subjected VSVs bearing all four $\mathrm{GP}(82 / 544)$ variants to in vitro proteolytic cleavage with CatL or THL (to mimic CatB activity) and analyzed the deglycosylated cleavage products by SDS-PAGE (Fig. 7A). With CatL treatment, we observed a rapid conversion to an 18,000-molecular-weight (18K) species $\left(G P 1_{18 \mathrm{~K}}\right)$ for all four GP variants. GPs with 82A were resistant to further proteolysis, as evidenced by the persistence of $\mathrm{GP} 1_{18 \mathrm{~K}}$ for up to $3 \mathrm{~h}$. GPs with $82 \mathrm{~V}$, in contrast, were converted to a novel GP1 cleavage product of $\sim 12 \mathrm{~K}$ in size $\left(\mathrm{GP} 1_{12 \mathrm{~K}}\right)$. Both $\mathrm{GP} 1_{18 \mathrm{~K}}$ and $\mathrm{GP} 1_{12 \mathrm{~K}}$ were degraded upon prolonged CatL treatment. Treatment with THL led only to the formation of the expected $17 \mathrm{~K}$ product $\left(\mathrm{GP} 1_{17 \mathrm{~K}}\right)$ for all four GP variants. No overt differences in susceptibility to THL were observed in $1 \mathrm{~h}$ of THL treatment. Therefore, the presence of $82 \mathrm{~V}$ appears to induce a specific change in GP sensitivity to CatL rather than a generalized change in its sensitivity to proteolysis (Fig. 7B).

Given that proteolysis by THL destabilized GPs bearing $82 \mathrm{~V}$, we investigated if proteolysis by CatL to this novel GP cleavage product represents an additionally destabilizing step. Accordingly, we exposed VSV-GP variants to CatL for $1 \mathrm{~h}$, at which point a maximal ratio of $\mathrm{GP}_{12 \mathrm{~K}}$ to $\mathrm{GP}_{18 \mathrm{~K}}$ was achieved, before measuring GP thermostability. Since CatL-cleaved GP is not recognized by KZ52, we made use of a monoclonal antibody (mAb) (ADI-15878) targeting a partially overlapping epitope in order to measure conformational intactness following heating $(26,30)$. We observed a pattern of melting temperatures that is strikingly similar to that of THL-treated GP, although the differences between GP variants were not statistically significant (Fig. $8 \mathrm{~A}$ to D). Thus, the appearance of the $\mathrm{GP}_{12 \mathrm{~K}}$ cleavage product does not seem to be accompanied by any detectable additional destabilization of GP.

We also measured the relative infectivity of VSV-GP variants following a 1-h 

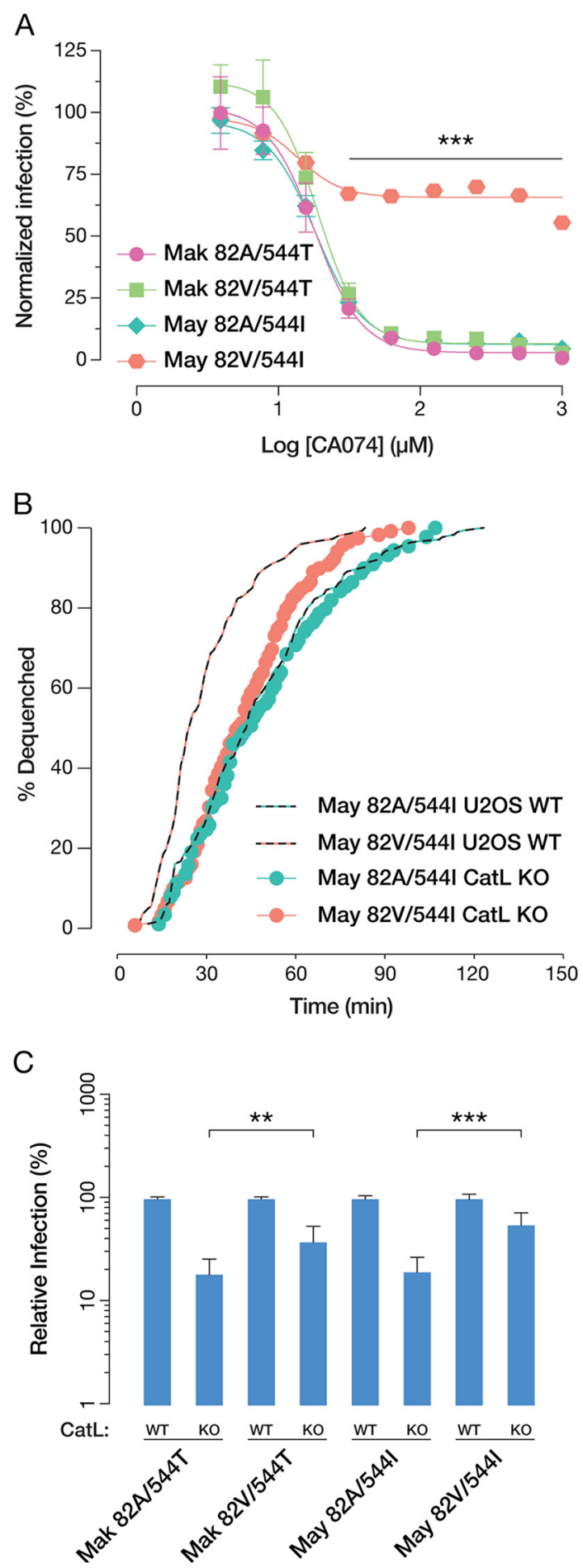

FIG 6 (A) Normalized infectivity levels at various concentrations of the CatB inhibitor CA074. Means $( \pm S D)$ of results from two independent experiments with three technical replicates $(n=6)$ are shown. At concentrations of CA074 of $>15 \mu \mathrm{M}$, VSV-GP(May $82 \mathrm{~V} / 544 \mathrm{I}$ ) is significantly more infectious than all other GP variants $(P<0.001$ [by multiple $t$ tests with the Holm-Šídák correction for multiple testing]). (B) Kinetics of viral fusion triggering for VSV-GP(May 82V/544I) and VSV-GP(May 82A/544I) in U2OS CatL KO cells. (C) WT and CatL KO U2OS cells were infected with VSV-GP variants, and infectivity was scored by automatic counting of GFP-positive cells at $14 \mathrm{~h}$ postinfection. Groups were compared by one-way ANOVA with Šídák correction for multiple testing in order to determine statistical significance $\left({ }^{*}, P<0.033 ;{ }^{* *}, P<0.002 ;{ }^{* * *}, P<0.001\right)$. On CatL KO cells, viruses carrying $82 \mathrm{~V}$ variants have higher relative infectivity than those carrying $82 \mathrm{~A}$. Means $( \pm S D$ ) of results from nine trials from three independent experiments with three technical replicates are shown. 
A
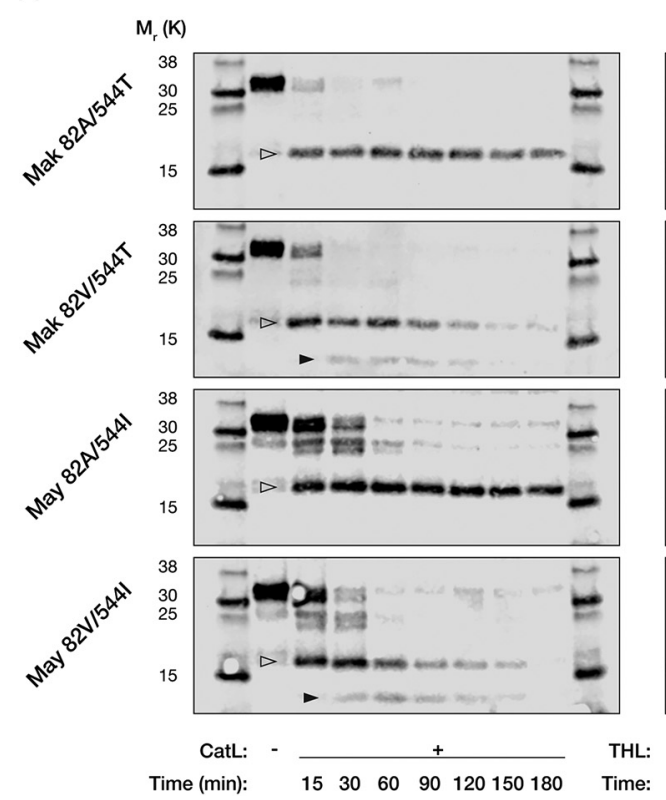

B

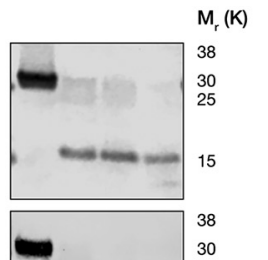

C

$\mathrm{M}_{\mathrm{r}}(\mathrm{K})$

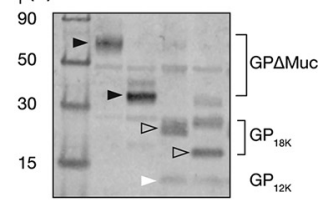

Catl: - - + +

FIG 7 (A) Representative Western blots of GP1 CatL cleavage products analyzed by SDS-PAGE following PNGase $F$ treatment. With increased incubation times ( 0 to $3 \mathrm{~h}$ ), GP variants bearing $82 \mathrm{~V}$ were converted to two distinct products of approximately $18 \mathrm{~K}$ and $12 \mathrm{~K}$, respectively. (B) Representative Western blots of GP1 THL cleavage products analyzed by SDS-PAGE following PNGase F treatment. No overt differences in proteolysis were observed between the GP variants. (C) Representative Western blot of CatL-treated and native VSV-GP (May 82V/544I), with or without PNGase F treatment, showing the glycosylation-dependent migration of GP (black arrows), $\mathrm{GP}_{18 \mathrm{~K}}$ (open arrows), and $\mathrm{GP}_{12 \mathrm{~K}}$ (white arrow).

incubation with CatL. While all variants displayed a decreased level of relative infectivity, the reduction in viral titers of variants bearing $82 \mathrm{~V}$ was significantly larger than that of variants bearing $82 \mathrm{~A}$ (Fig. $8 \mathrm{E}$ ), indicating that the generation of the $\mathrm{GP}_{12 \mathrm{~K}}$ species by precleavage with CatL is inactivating. We conclude that, unlike $\mathrm{GP}_{18 \mathrm{~K}}$ and $\mathrm{GP}_{17 \mathrm{~K}}, \mathrm{GP}_{12 \mathrm{~K}}$ does not represent a more fully primed prefusion conformer of GP and speculate that its generation must be coupled to cell entry in order to drive enhanced increased infectivity.

Because $\mathrm{GP}_{18 \mathrm{~K}}$ appears to chase into $\mathrm{GP} 1_{12 \mathrm{~K}}$, the latter must be derived by the cleavage of the former. Accordingly, we next sought to establish which GP1 sequences are lost upon $\mathrm{GP} 1_{18 \mathrm{~K}} \rightarrow \mathrm{GP} 1_{12 \mathrm{~K}}$ cleavage. Previous work indicates that CatL-cleaved WT Mayinga $\mathrm{GP} 1_{18 \mathrm{~K}}$ comprises GP1 residues 33 to 190 (31). Making use of the N-linked glycan at position 40 of $\mathrm{GP}_{18 \mathrm{~K}}$, the sole remaining glycan in this product (32), we analyzed the migration patterns of the VSV-GP(May 82V/544I) cleavage products prior to or following deglycosylation with protein- $N$-glycosidase $F$ (PNGase F). For intact GP1 $\Delta$ Muc and $\mathrm{GP} 1_{18 \mathrm{k}}$, we observed a shift in the electrophoretic mobility of these products upon PNGase $\mathrm{F}$ treatment, whereas $\mathrm{GP} 1_{12 \mathrm{~K}}$ was unaffected (Fig. $7 \mathrm{C}$ ). Thus, $\mathrm{N}$-terminal residues encompassing $\mathrm{N} 40$ are removed during $\mathrm{GP} 1_{18 \mathrm{~K}} \rightarrow \mathrm{GP}_{12 \mathrm{~K}}$ cleavage. Moreover, $\mathrm{GP}_{12 \mathrm{~K}}$ was recognized by an antiserum raised against a peptide comprising GP1 residues 83 to 97 (13) (Fig. 7A), indicating that it still contains this sequence. We propose, therefore, that the new $\mathrm{N}$-terminus generated by $\mathrm{GP} 1_{18 \mathrm{~K}} \rightarrow \mathrm{GP}_{12 \mathrm{~K}}$ cleavage lies between GP1 residues 41 and 83 . Whether $\mathrm{GP} 1_{18 \mathrm{~K}}$ also undergoes $\mathrm{C}$-terminal cleavage remains unknown at present.

\section{DISCUSSION}

The 2013-2016 EBOV epidemic in West Africa led to an unprecedented number of infections and deaths but has enabled the first opportunity to examine how the virus evolves during prolonged human-to-human transmission. Viral sequences sampled during this epidemic revealed several nonsynonymous mutations 
A

GP $\sim 15878$

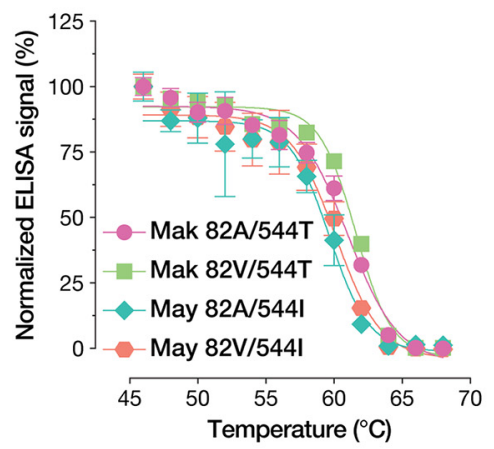

C

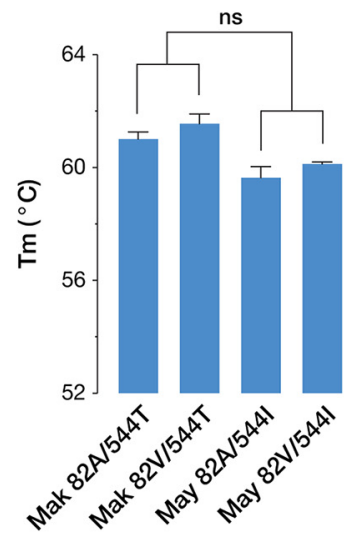

B

GP+CatL 15878

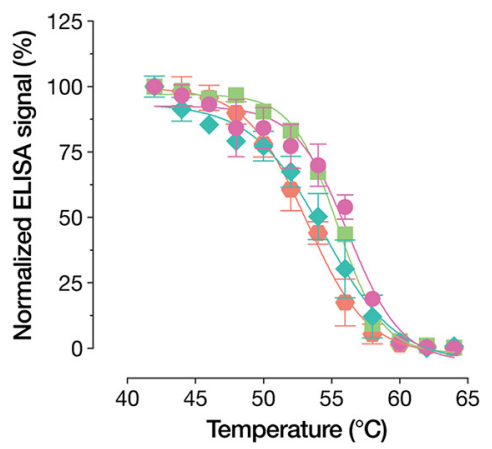

$\mathrm{D}$

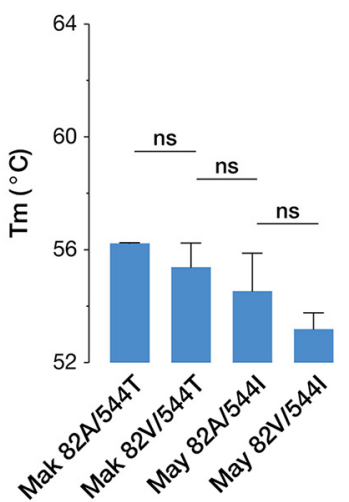

E

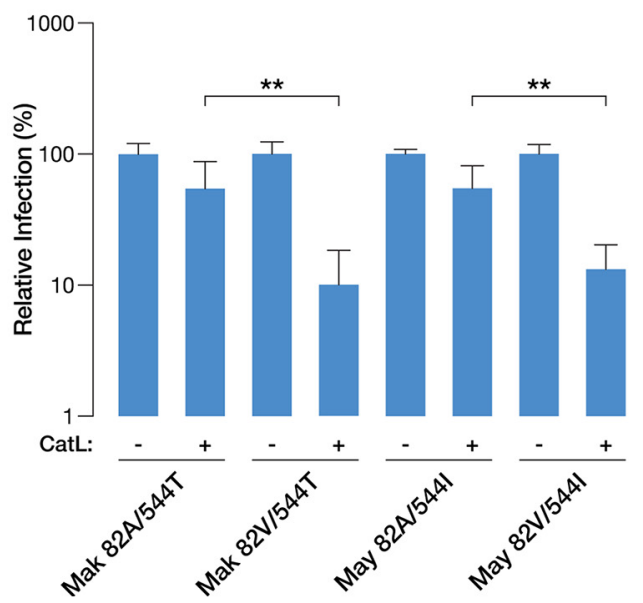

FIG 8 (A and B) Normalized ELISA signals of ADI-15878 binding to native (A) and CatL-treated (B) VSV-GP variants following heating. Means $( \pm S D)$ of results from two independent experiments with three technical replicates $(n=6)$ are shown. (C and D) $T_{m}$ values for native (C) and CatL-treated (D) VSV-GP variants, derived by nonlinear regression analysis of ELISA signals. Statistical significance was determined by one-way ANOVA with Tukey correction for multiple testing ( $\mathrm{ns}$, not significant $[P>0.05]$ ). (E) Relative infectivity of native and CatL-treated VSV-GP variants. Statistical significance was determined by one-way ANOVA with Šídák correction for multiple testing. Means $( \pm S D)$ of results from two independent experiments with three technical replicates $(n=6)$ are shown.

compared to the EBOV Mayinga reference strain isolated in 1976 following limited human-to-human transmission (1-4). Two of these polymorphisms in GP, at positions 82 and 544, were previously shown to have opposing impacts on viral infectivity $(15,16)$. Here, we show that these mutations affect distinct steps in EBOV entry, 
which points toward a novel mechanistic basis for the increased infectivity of the A82V mutation.

EBOV entry into cells depends on a number of host factors, including the cysteine proteases CatB and CatL that act on GP to reveal the binding site $(13,14)$ for the universal filovirus receptor NPC1 $(11,12)$. Evidence suggests that these factors, while critical for entry, are insufficient to elicit GP membrane fusion $(20,33,34)$ and that an additional host factor, acting as a fusion trigger, must exist.

Although viral fusion glycoproteins can be primed and triggered by many different factors, thermostability serves as a good general proxy for their capacity to undergo fusogenic conformational changes $(24,35,36)$. We found that GPs bearing 544 I were less thermostable than GPs bearing 544T, regardless of the residue at position 82 , and that THL-cleaved GP exhibited incremental destabilization, with both $82 \mathrm{~V}$ and $544 \mathrm{I}$ contributing to reduced stability versus their $82 \mathrm{~A}$ and $544 \mathrm{~T}$ counterparts. Similar results were observed for CatL-cleaved GPs, suggesting that the differences observed between the GP variants are not protease specific but rather reflect general changes in stability. We propose that polymorphisms at position 544 primarily influence global GP stability, which may have ramifications for initial proteolytic cleavages in GP or even for fusogenic rearrangement. Due to its location in the GP2 internal fusion loop, residue 544 has been speculated to alter fusogenicity and/or bilayer insertion $(10,17,18,37)$. In GP peptides at low $\mathrm{pH}, 544 \mathrm{I}$ forms part of a "hydrophobic fist" together with 529L and 535F, which is proposed to be necessary for penetration of the host membrane (38). Although this study did not examine the effect of polymorphisms at position 544 , we found no gross defect in fusion triggering or hemifusion in cells, only a significant delay in fusion kinetics between mutants bearing $\mathrm{T}$ or I at this position.

Although $544 \mathrm{l}$ has been demonstrated to increase infectivity in cell lines derived from different hosts, the promotion of infection by $82 \mathrm{~V}$ occurs selectively (37), suggesting that its basis for enhanced infectivity is host species dependent. Some evidence for $82 \mathrm{~V}$-induced instability lies in the mutant's 3.47 resistance and decreased $T_{m}$ values, but we argue that this is secondary to $82 \mathrm{~V}$ 's role in facilitating GP cleavage by CatL. Cell type-dependent differences in CatL abundance or activity may explain the selectively heightened infectivity of $82 \mathrm{~V}$ better than differences in NPC1 interaction.

The relative instability of GP bearing $82 \mathrm{~V}$ has been cited as the primary source of its enhanced infectivity (10). Interestingly, we saw that fusion triggering occurred more rapidly for GPs bearing $82 \mathrm{~V}, 544 \mathrm{I}$, or a combination thereof, as measured by overall lipid mixing rates and time to fusion following delivery to NPC1-positive compartments. Although our live assays were unable to monitor the infection success of any given membrane fusion event, earlier triggering of viruses is generally associated with increased infectivity $(39,40)$. In addition to driving more rapid viral entry, the higher rates of fusion may enhance the probability of successful viral escape into the cytoplasm by facilitating evasion of the harsh conditions in the lysosome and/or lysosometargeted host antiviral factors such as the late endosomal/lysosomal interferoninduced transmembrane proteins (IFITMs) $(28,41)$. We also found that the high rate of lipid mixing of $82 \mathrm{~V}$ variants is mediated by a CatL-dependent activity, as the kinetics of lipid mixing by VSV-GP(May 82V/544I) and VSV-GP(May 82A/544I) were largely the same in cells lacking CatL.

These observations are in contrast to the in vitro proteolytic cleavage of GP by CatL, which is promoted specifically by the presence of $82 \mathrm{~V}$ but not $544 \mathrm{I}$. GPs bearing $82 \mathrm{~V}$ were both more labile and, intriguingly, processed to a novel GP1 cleavage product of approximately $12 \mathrm{~K}$ in size $\left(\mathrm{GP} 1_{12 \mathrm{~K}}\right)$. Our approximate mapping of this newly identified novel cleavage product indicates that the $\mathrm{GP} 1_{18 \mathrm{~K}}$ product usually obtained with WT GP undergoes further $\mathrm{N}$-terminal cleavage by CatL to remove as many as 50 additional amino acid residues. This altered pattern of proteolytic cleavage was not observed following treatment with $\mathrm{THL}$, but it may extend beyond CatL in cells since a relative increase in infectivity was observed in U2OS cells lacking CatL. If cleaved by CatL in order to enrich for $\mathrm{GP}_{12 \mathrm{~K}}, 82 \mathrm{~V}$ variants instead display decreased infectivity, suggesting 
that this product could represent a pretriggered form of GP. The temporal and spatial coordination of the generation of this form of GP may be required to drive enhanced viral entry by GP variants bearing A82V.

Our findings suggest that residue 544 acts as a regulator of infectivity in cell culture by modulating overall GP stability and fusogenicity, whereas residue 82 more specifically influences proteolytic cleavage of GP by host endosomal cysteine cathepsins. This is reflected in increased relative infectivity under conditions where cysteine cathepsin activity is depleted, either genetically or by chemical inhibition, as well as in increased proteolysis in vitro with the appearance of a novel cleavage product. Combining these effects affords an increase in the kinetics of fusion, explaining the previously observed increase in infectivity of the $\mathrm{GP}(82 \mathrm{~V} / 544 \mathrm{I})$ double mutant.

We recently showed that a mutation near the $\mathrm{N}$ terminus of GP1, R64A, inhibited viral membrane fusion and entry in a manner reversible by second-site mutations near the GP1 N terminus (24). These second-site reversions were predicted to destabilize GP and enhance the exposure of GP1 N-terminal sequences to proteolysis. Our current findings argue that $\mathrm{A} 82 \mathrm{~V}$ accelerates viral membrane fusion and increases viral entry through a related mechanism: enhancing proteolytic cleavage at $\mathrm{N}$-terminal sequences in GP1. Although more work is needed, both sets of observations are concordant with a hypothesis in which conformational changes at the GP1 base, coupled to NPC1 recognition by the receptor-binding site in the GP1 head, expose the base to further proteolytic cleavages that drive fusogenic rearrangement. We speculate that these GP1 $\mathrm{N}$-terminal cleavages are normally mediated by the sequential activity of endosomal cysteine aminopeptidases such as $\mathrm{CatC}$ or $\mathrm{CatH}$ but can be more promiscuously carried out by cysteine endoproteases like CatL in the context of the A82V mutation, thereby contributing to the observed enhancements in viral entry and infection.

\section{MATERIALS AND METHODS}

Cells, viruses, and infection conditions. All infection experiments were carried out in Vero cells cultured in Dulbecco's modified Eagle medium (DMEM) (Life Technologies, Carlsbad, CA) supplemented with $2 \%$ fetal bovine serum (FBS) (Atlanta Biologicals, Flowery Branch, GA), 1\% penicillin-streptomycin (Life Technologies, Carlsbad, CA), and 1\% GlutaMAX (Life Technologies, Carlsbad, CA) or in U2OS cells cultured in McCoy's 5A modified medium (Life Technologies, Carlsbad, CA) supplemented with $10 \%$ fetal bovine serum (Atlanta Biologicals, Flowery Branch, GA), 1\% penicillin-streptomycin (Life Technologies, Carlsbad, CA), and 1\% GlutaMAX (Life Technologies, Carlsbad, CA). U2OS cells stably expressing monomeric NeonGreen fused to NPC1 (NPC1-mNG) were generated as previously described (27).

Pseudotyped VSVs bearing mutant EBOV GPs were generated as described previously $(29,42)$. Mutant Mayinga GPs were based on the EBOV/H.sapiens-tc/COD/1976/Yambuku-Mayinga isolate amino acid sequence (GenBank accession number AF086833). Mutant Makona GPs were based on EBOV/H.sapiens-wt/LBR/2015/Makona-LIBR16393 (GenBank accession number KY744596). All GPs included a deletion of the mucin domain $(\Delta 309-489)(43)$.

Prior to infection experiments, confluent Vero or U2OS cells were seeded in their respective growth media described above. VSVs bearing mutant GPs were diluted in the corresponding media before addition to cells. Infected cells were then maintained at $37^{\circ} \mathrm{C}$ for 14 to $16 \mathrm{~h}$ postinfection before automatic counting of green fluorescent protein (GFP)-positive cells using a Cytation 5 cell imaging multimode reader (BioTek Instruments, Winooski, VT) and using the onboard software for calculations of the percentage of infected cells.

NPC1 domain C ELISA. Plates were coated with GP-specific mAb KZ52 (44) diluted to $2 \mu \mathrm{g} / \mathrm{ml}$ in phosphate-buffered saline (PBS). VSV-GP mutants were normalized for GP content and then incubated at $37^{\circ} \mathrm{C}$ for $1 \mathrm{~h}$ in the presence of $250 \mu \mathrm{g} / \mathrm{ml}$ thermolysin (Sigma-Aldrich, St. Louis, MO), before the addition of $10 \mathrm{mM}$ phosphoramidon to stop the reaction. ELISA plates were blocked using PBS supplemented with $3 \%$ bovine serum albumin (PBSA) (Thermo Fisher Scientific, Waltham, MA). THL-treated virus was added to blocked KZ52-coated plates and allowed to adsorb at $37^{\circ} \mathrm{C}$ for $1 \mathrm{~h}$. Following washing with 3\% PBSA, a dilution series of FLAG-tagged NPC1 domain C (45) was added and allowed to bind for $1 \mathrm{~h}$ at $37^{\circ} \mathrm{C}$. Bound domain $\mathrm{C}$ was then detected using a horseradish peroxidase (HRP)-conjugated antiFLAG antibody (Ab) (Sigma-Aldrich, St. Louis, MO) and the Ultra-TMB substrate (Thermo Fisher Scientific, Waltham, MA). Fifty percent effective concentration $\left(\mathrm{EC}_{50}\right)$ values were calculated using nonlinear regression of data from two independent experiments with three technical replicates each.

CA074 and 3.47 inhibitor experiments. The viral inhibitors 3.47 (Microbiotix, Worcester, MA) and CA074 (Sigma-Aldrich, St. Louis, MO) were reconstituted in dimethyl sulfoxide (DMSO). Twofold dilution series starting at $100 \mu \mathrm{M}$ and $1 \mathrm{mM}$, respectively, were then made in complete DMEM (Life Technologies, Grand Island, NY) supplemented with 2\% fetal bovine serum (Atlanta Biologicals, Flowery Branch, GA), 1\% penicillin-streptomycin (Life Technologies, Carlsbad, CA), and 1\% GlutaMAX (Life Technologies, Carlsbad, CA). Diluted inhibitors were then added to confluent Vero cells, and uptake was allowed to proceed 
through $4 \mathrm{~h}$ of incubation at $37^{\circ} \mathrm{C}$. VSV-GP mutants were then diluted 1:1,000 in complete DMEM and added to inhibitor-treated cells. At 14 to $16 \mathrm{~h}$ postinfection, cells were fixed in $4 \%$ paraformaldehyde (PFA) and stained with Hoechst nuclear stain before GFP-positive cells were counted using a Cytation 5 cell imaging multimode reader (BioTek Instruments, Winooski, VT) with the onboard software for calculations of the percentage of infected cells.

In vitro proteolysis. VSV-GP mutants, normalized for GP content and corresponding to between $2 \times 10^{5}$ and $2 \times 10^{6} \mathrm{IU}$, were incubated with activated human recombinant CatL (R\&D Systems, Minneapolis, MN) at $2 \mathrm{ng} / \mu \mathrm{l}$ or THL (Sigma-Aldrich, St. Louis, MO) at $250 \mu \mathrm{g} / \mathrm{ml}$. Cleavage by CatL was allowed to proceed at $37^{\circ} \mathrm{C}$ for $15,30,60,90,120,150$, or $180 \mathrm{~min}$ before the reaction was stopped by the addition of $0.1 \mathrm{mM} \mathrm{E}-64$. Cleavage by THL was allowed to proceed at $37^{\circ} \mathrm{C}$ for 30,60 , or $120 \mathrm{~min}$ before the reaction was stopped by the addition of $10 \mathrm{mM}$ phosphoramidon. Cleavage products were then deglycosylated by treatment with 250 U PNGase F (New England BioLabs, Ipswich, MA) for $16 \mathrm{~h}$ at $37^{\circ} \mathrm{C}$. Parallel samples of VSV-GP(May $\left.82 \mathrm{~V} / 544 \mathrm{I}\right)$ treated with CatL for $60 \mathrm{~min}$ were also left without deglycosylation for the analysis of the presence of the glycan at N40.

SDS-PAGE and Western blotting. Deglycosylated and native samples containing GP cleavage products were analyzed by SDS-PAGE using 10\% Tricine protein gels (Thermo Fisher Scientific, Waltham, MA). Samples were transferred onto 0.2- $\mu \mathrm{m}$-pore-size Protran nitrocellulose membranes (Sigma-Aldrich, St. Louis, MO) followed by Western blotting for GP1 using a rabbit polyclonal serum recognizing a peptide (TKRWGFRSGVPPKVV) overlapping the receptor-binding site. IRDye 680LT goat anti-rabbit IgG 680 secondary $\mathrm{Ab}$ (Li-Cor, Lincoln, NE) was used at a dilution of 1:10,000, and the final blot was then imaged using a Li-Cor Fc fluorescence imager.

GP thermostability assay. A GP thermostability assay was conducted as previously described (24). VSVs bearing mutant GPs were treated with $\mathrm{THL}$ at $500 \mu \mathrm{g} / \mathrm{ml}$ for $30 \mathrm{~min}$ at $37^{\circ} \mathrm{C}$, or mock treated, before the addition of $10 \mathrm{mM}$ phosphoramidon to stop the reaction. Cleaved and uncleaved viruses were diluted in PBS and then heated at a range of temperatures spanning from $42^{\circ} \mathrm{C}$ to $64^{\circ} \mathrm{C}$ (cleaved) and $46^{\circ} \mathrm{C}$ to $68^{\circ} \mathrm{C}$ (uncleaved) for $10 \mathrm{~min}$, followed by cooling to $4^{\circ} \mathrm{C}$ using a thermal cycler (Applied Biosystems, Foster City, CA). After cooling, virus was directly captured onto high-binding 96-well halfarea ELISA plates (Corning, Corning, NY). Plates were then blocked using $3 \%$ bovine serum albumin in PBS. GP was detected using KZ52 or ADI-15878, two conformation-specific anti-EBOV GP monoclonal antibodies. Antibody bound to GP was then detected with anti-human antibody conjugated to HRP (EMD Millipore, Burlington, MA) and the Ultra-TMB substrate (Thermo Fisher, Grand Island, NY). All binding steps were carried out at $37^{\circ} \mathrm{C}$ for $1 \mathrm{~h}$. Binding curves were generated using Prism (nonlinear regression, variable slope [four parameters]; GraphPad Software, La Jolla, CA). $T_{m}$ values were calculated from two independent experiments, each with three replicates.

Virus labeling for live-cell microscopy. Purified virus $(1 \mathrm{mg} / \mathrm{ml})$ was labeled with $50 \mu \mathrm{M} 1,1^{\prime}$-dioctadecyl-3,3,3',3'-tetramethylindodicarbocyanine (DiD) dye while being agitated for $1 \mathrm{~h}$ at $4^{\circ} \mathrm{C}$. Excess dye was removed by ultracentrifugation of the virus through a $10 \%$ sucrose cushion for $2 \mathrm{~h}$ at $107,000 \times g$ at $4^{\circ} \mathrm{C}$ using an SW41 rotor (Beckman Coulter). Labeled virus pellets were resuspended at a viral protein concentration of $1 \mathrm{mg} / \mathrm{ml}$, aliquoted, and stored at $-80^{\circ} \mathrm{C}$ until use.

Live imaging. Live-cell microscopy was performed as previously described (28) with an AxioObserver. Z1 wide-field epifluorescence microscope (Zeiss, Oberkochen, Germany) equipped with a 40×/1.3-numerical-aperture (NA) objective, a DAPI (4',6-diamidino-2-phenylindole)/GFP/Texas Red/Cy5 filter set, and a heated environmental enclosure maintained at $37^{\circ} \mathrm{C}$. U2OS cell monolayers were seeded onto fibronectincoated 35-mm glass coverslip dishes (MatTek, Ashland, MA) $24 \mathrm{~h}$ before experiments. Cells were chilled for several minutes on ice before spinoculation of DiD-labeled virus onto monolayers at $1,500 \times g$ at $6^{\circ} \mathrm{C}$ for $20 \mathrm{~min}$. Unbound particles were removed by five washes with cold PBS, and $500 \mu \mathrm{l}$ cold imaging buffer $(140 \mathrm{mM} \mathrm{NaCl}, 2.5 \mathrm{mM} \mathrm{KCl}, 1.8 \mathrm{mM} \mathrm{MgCl} 2,20 \mathrm{mM}$ HEPES, $5 \mathrm{mM}$ sucrose, $2 \mu \mathrm{M}$ Hoechst 33342, and 2\% FBS) was added to cover the cells. The dish was immediately mounted on the microscope objective and focused. The coverslip dish was then flooded with $1.5 \mathrm{ml}$ warm imaging buffer to mark the start of experiments $(t=0)$. Images were acquired every $10 \mathrm{~s}$ for the duration of the experiments using a single $z$-section, which encompassed nearly all cell-associated particles.

Data analysis. Image analysis and single-particle tracking were performed using Volocity software (PerkinElmer, Waltham, MA) as previously described (27). Image files were not manipulated, apart from minor adjustments in brightness and contrast. Viral puncta were thresholded by initial intensity and size. Puncta falling outside the range of the 0.25 to $1 \mu \mathrm{m}^{2}$ expected of individual DiD-labeled virions were excluded from single-particle analysis. Virions were considered colocalized with NPC1 or Rab5 only if the cellular marker punctum exceeded the background signal by $30 \%$ or more and if the intracellular and viral puncta cotrafficked with a $>70 \%$ overlap of signals. Mean measurements $( \pm$ standard deviations [SD]) were derived from three separate experiments unless otherwise indicated.

Statistics and reproducibility. Experiments were performed using two independently generated viral stocks or one viral stock benchmarked to historical stocks in terms of titer and GP incorporation. All data represent results from two or three independent experiments, each with two or three replicates ( $n=6$ in all instances). Western blots are representative of experiments performed at least 3 times.

The appropriate statistical analysis was applied to each experiment. Viral titers were compared by unpaired two-tailed $t$ tests. Sensitivities to 3.47 and CA074 were compared by multiple $t$ tests, with Holm-Šídák correction for multiple testing. Melting temperatures and lipid mixing kinetics were compared using one-way analysis of variance (ANOVA) with Tukey correction for multiple testing. Relative infectivities in CatL KO cells, and by CatL-treated virus, were compared by one-way ANOVA with Šídák correction for multiple testing. Significance levels are indicated in each figure legend through the use of asterisks. 


\section{ACKNOWLEDGMENTS}

We thank I. Gutierrez, E. Valencia, L. Polanco, C. Harold, and T. Krause for laboratory

management and technical support. We also thank $\mathrm{M}$. $\mathrm{Ng}$ for providing reagents and

for exploratory work related to this project.

We acknowledge funding support from NIH R01 Al134824 (to K.C.).

\section{REFERENCES}

1. Baize S, Pannetier D, Oestereich L, Rieger T, Koivogui L, Magassouba N, Soropogui B, Sow MS, Keïta S, De Clerck H, Tiffany A, Dominguez G, Loua $M$, Traoré A, Kolié M, Malano ER, Heleze E, Bocquin A, Mély S, Raoul H, Caro V, Cadar D, Gabriel M, PahImann M, Tappe D, Schmidt-Chanasit J, Impouma B, Diallo AK, Formenty P, Van Herp M, Günther S. 2014. Emergence of Zaire Ebola virus disease in Guinea. N Engl J Med 371:1418-1425. https://doi.org/ 10.1056/NEJMoa1404505.

2. Carroll MW, Matthews DA, Hiscox JA, Elmore MJ, Pollakis G, Rambaut A, Hewson R, García-Dorival I, Bore JA, Koundouno R, Abdellati S, Afrough B, Aiyepada J, Akhilomen P, Asogun D, Atkinson B, Badusche M, Bah A, Bate S, Baumann J, Becker D, Becker-Ziaja B, Bocquin A, Borremans B, Bosworth A, Boettcher JP, Cannas A, Carletti F, Castilletti C, Clark S, Colavita F, Diederich S, Donatus A, Duraffour S, Ehichioya D, Ellerbrok H, Fernandez-Garcia MD, Fizet A, Fleischmann E, Gryseels S, Hermelink A, Hinzmann J, Hopf-Guevara U, Ighodalo Y, Jameson L, Kelterbaum A, Kis Z, Kloth S, Kohl C, Korva M, et al. 2015. Temporal and spatial analysis of the 2014-2015 Ebola virus outbreak in West Africa. Nature 524:97-101. https://doi.org/10.1038/nature14594.

3. Gire SK, Goba A, Andersen KG, Sealfon RSG, Park DJ, Kanneh L, Jalloh S, Momoh M, Fullah M, Dudas G, Wohl S, Moses LM, Yozwiak NL, Winnicki S, Matranga CB, Malboeuf CM, Qu J, Gladden AD, Schaffner SF, Yang X, Jiang P-P, Nekoui M, Colubri A, Coomber MR, Fonnie M, Moigboi A, Gbakie M, Kamara FK, Tucker V, Konuwa E, Saffa S, Sellu J, Jalloh AA, Kovoma A, Koninga J, Mustapha I, Kargbo K, Foday M, Yillah M, Kanneh F, Robert W, Massally JLB, Chapman SB, Bochicchio J, Murphy C, Nusbaum C, Young S, Birren BW, Grant DS, Scheiffelin JS, et al. 2014. Genomic surveillance elucidates Ebola virus origin and transmission during the 2014 outbreak. Science 345:1369-1372. https://doi.org/10.1126/science.1259657.

4. Ladner JT, Wiley MR, Mate S, Dudas G, Prieto K, Lovett S, Nagle ER, Beitzel B, Gilbert ML, Fakoli L, Diclaro JW, Schoepp RJ, Fair J, Kuhn JH, Hensley LE, Park DJ, Sabeti PC, Rambaut A, Sanchez-Lockhart M, Bolay FK, Kugelman JR, Palacios G. 2015. Evolution and spread of Ebola virus in Liberia, 20142015. Cell Host Microbe 18:659-669. https://doi.org/10.1016/j.chom.2015 .11 .008 .

5. Kuhn JH, Andersen KG, Baize S, Bào Y, Bavari S, Berthet N, Blinkova O, Brister JR, Clawson AN, Fair J, Gabriel M, Garry RF, Gire SK, Goba A, Gonzalez J-P, Günther S, Happi CT, Jahrling PB, Kapetshi J, Kobinger G, Kugelman JR, Leroy EM, Maganga GD, Mbala PK, Moses LM, MuyembeTamfum J-J, N'Faly M, Nichol ST, Omilabu SA, Palacios G, Park DJ, Paweska JT, Radoshitzky SR, Rossi CA, Sabeti PC, Schieffelin JS, Schoepp RJ, Sealfon R, Swanepoel R, Towner JS, Wada J, Wauquier N, Yozwiak NL, Formenty P. 2014. Nomenclature- and database-compatible names for the two Ebola virus variants that emerged in Guinea and the Democratic Republic of the Congo in 2014. Viruses 6:4760-4799. https://doi.org/10.3390/v6114760.

6. Dietzel E, Schudt G, Krähling V, Matrosovich M, Becker S. 2017. Functional characterization of adaptive mutations during the West African Ebola virus outbreak. J Virol 91:e01913-16. https://doi.org/10.1128/JVI.01913-16.

7. Diehl WE, Lin AE, Grubaugh ND, Carvalho LM, Kim K, Kyawe PP, McCauley SM, Donnard E, Kucukural A, McDonel P, Schaffner SF, Garber M, Rambaut A, Andersen KG, Sabeti PC, Luban J. 2016. Ebola virus glycoprotein with increased infectivity dominated the 2013-2016 epidemic. Cell 167:1088-1098.e6. https:// doi.org/10.1016/j.cell.2016.10.014.

8. Urbanowicz RA, McClure CP, Sakuntabhai A, Sall AA, Kobinger G, Müller MA, Holmes EC, Rey FA, Simon-Loriere E, Ball JK. 2016. Human adaptation of Ebola virus during the West African outbreak. Cell 167:1079-1087.e5. https://doi.org/10.1016/j.cell.2016.10.013.

9. Marzi A, Chadinah S, Haddock E, Feldmann F, Arndt N, Martellaro C, Scott DP, Hanley PW, Nyenswah TG, Sow S, Massaquoi M, Feldmann H. 2018. Recently identified mutations in the Ebola virus-Makona genome do not alter pathogenicity in animal models. Cell Rep 23:1806-1816. https://doi .org/10.1016/j.celrep.2018.04.027.

10. Wang MK, Lim S-Y, Lee SM, Cunningham JM. 2017. Biochemical basis for increased activity of Ebola glycoprotein in the 2013-16 epidemic. Cell Host Microbe 21:367-375. https://doi.org/10.1016/j.chom.2017.02.002.
11. Carette JE, Raaben $M$, Wong AC, Herbert AS, Obernosterer G, Mulherkar N, Kuehne Al, Kranzusch PJ, Griffin AM, Ruthel G, Dal Cin P, Dye JM, Whelan SP, Chandran K, Brummelkamp TR. 2011. Ebola virus entry requires the cholesterol transporter Niemann-Pick C1. Nature 477:340-343. https://doi.org/ 10.1038 /nature 10348 .

12. Côté M, Misasi J, Ren T, Bruchez A, Lee K, Filone CM, Hensley L, Li Q, Ory D, Chandran K, Cunningham J. 2011. Small molecule inhibitors reveal Niemann-Pick C1 is essential for Ebola virus infection. Nature 477:344-348. https://doi.org/10.1038/nature10380.

13. Chandran K, Sullivan NJ, Felbor U, Whelan SP, Cunningham JM. 2005. Endosomal proteolysis of the Ebola virus glycoprotein is necessary for infection. Science 308:1643-1645. https://doi.org/10.1126/science.1110656.

14. Schornberg K, Matsuyama S, Kabsch K, Delos S, Bouton A, White J. 2006. Role of endosomal cathepsins in entry mediated by the Ebola virus glycoprotein. J Virol 80:4174-4178. https://doi.org/10.1128/JVI.80.8.4174-4178 .2006 .

15. Hoffmann M, Crone L, Dietzel E, Paijo J, González-Hernández M, Nehlmeier I, Kalinke U, Becker S, Pöhlmann S. 2017. A polymorphism within the internal fusion loop of the Ebola virus glycoprotein modulates host cell entry. J Virol 91:e00177-17. https://doi.org/10.1128/JVI.00177-17.

16. Ueda MT, Kurosaki Y, Izumi T, Nakano Y, Oloniniyi OK, Yasuda J, Koyanagi Y, Sato K, Nakagawa S. 2017. Functional mutations in spike glycoprotein of Zaire ebolavirus associated with an increase in infection efficiency. Genes Cells 22:148-159. https://doi.org/10.1111/gtc.12463.

17. Ruedas JB, Ladner JT, Ettinger CR, Gummuluru S, Palacios G, Connor JH. 2017. Spontaneous mutation at amino acid 544 of the Ebola virus glycoprotein potentiates virus entry and selection in tissue culture. J Virol 91: e00392-17. https://doi.org/10.1128/JVI.00392-17.

18. Ruedas JB, Arnold CE, Palacios G, Connor JH. 2018. Growth-adaptive mutations in the Ebola virus Makona glycoprotein alter different steps in the virus entry pathway. J Virol 92:e00820-18. https://doi.org/10.1128/JVI .00820-18.

19. Kaletsky RL, Simmons G, Bates P. 2007. Proteolysis of the Ebola virus glycoproteins enhances virus binding and infectivity. J Virol 81:13378-13384. https://doi.org/10.1128/JVI.01170-07.

20. Miller EH, Obernosterer G, Raaben M, Herbert AS, Deffieu MS, Krishnan A, Ndungo E, Sandesara RG, Carette JE, Kuehne Al, Ruthel G, Pfeffer SR, Dye JM, Whelan SP, Brummelkamp TR, Chandran K. 2012. Ebola virus entry requires the host-programmed recognition of an intracellular receptor. EMBO J 31:1947-1960. https://doi.org/10.1038/emboj.2012.53.

21. Ndungo E, Herbert AS, Raaben M, Obernosterer G, Biswas R, Miller EH, Wirchnianski AS, Carette JE, Brummelkamp TR, Whelan SP, Dye JM, Chandran K. 2016. A single residue in Ebola virus receptor NPC1 influences cellular host range in reptiles. mSphere 1:e00007-16. https://doi.org/ 10.1128/mSphere.00007-16.

22. Shoemaker CJ, Schornberg KL, Delos SE, Scully C, Pajouhesh H, Olinger GG, Johansen LM, White JM. 2013. Multiple cationic amphiphiles induce a Niemann-Pick $C$ phenotype and inhibit Ebola virus entry and infection. PLoS One 8:e56265. https://doi.org/10.1371/journal.pone.0056265.

23. Mittler E, Alkutkar T, Jangra RK, Chandran K. 2021. Direct intracellular visualization of Ebola virus-receptor interaction by in situ proximity ligation. mBio 12:e03100-20. https://doi.org/10.1128/mBio.03100-20.

24. Fels JM, Spence JS, Bortz RH, Bornholdt ZA, Chandran K. 2019. A hyperstabilizing mutation in the base of the Ebola virus glycoprotein acts at multiple steps to abrogate viral entry. mBio 10:e01408-19. https://doi.org/10 .1128/mBio.01408-19.

25. Brecher M, Schornberg KL, Delos SE, Fusco ML, Saphire EO, White JM. 2012. Cathepsin cleavage potentiates the Ebola virus glycoprotein to undergo a subsequent fusion-relevant conformational change. J Virol 86:364-372. https://doi.org/10.1128/JVI.05708-11.

26. Bortz RH, Wong AC, Grodus MG, Recht HS, Pulanco MC, Lasso G, Anthony SJ, Mittler E, Jangra RK, Chandran K. 2020. A virion-based assay for 
glycoprotein thermostability reveals key determinants of filovirus entry and its inhibition. J Virol 94:e00336-20. https://doi.org/10.1128/JVI.00336 -20 .

27. Spence JS, Krause TB, Mittler E, Jangra RK, Chandran K. 2016. Direct visualization of Ebola virus fusion triggering in the endocytic pathway. mBio 7: e01857-15. https://doi.org/10.1128/mBio.01857-15.

28. Spence JS, He R, Hoffmann H-H, Das T, Thinon E, Rice CM, Peng T, Chandran K, Hang HC. 2019. IFITM3 directly engages and shuttles incoming virus particles to lysosomes. Nat Chem Biol 15:259-268. https://doi .org/10.1038/s41589-018-0213-2.

29. Wong AC, Sandesara RG, Mulherkar N, Whelan SP, Chandran K. 2010. A forward genetic strategy reveals destabilizing mutations in the ebolavirus glycoprotein that alter its protease dependence during cell entry. J Virol 84:163-175. https://doi.org/10.1128/JVI.01832-09.

30. Wec AZ, Herbert AS, Murin CD, Nyakatura EK, Abelson DM, Fels JM, He S, James RM, de La Vega M-A, Zhu W, Bakken RR, Goodwin E, Turner HL, Jangra RK, Zeitlin L, Qiu X, Lai JR, Walker LM, Ward AB, Dye JM, Chandran K, Bornholdt ZA. 2017. Antibodies from a human survivor define sites of vulnerability for broad protection against ebolaviruses. Cell 169:878-890. e15. https://doi.org/10.1016/j.cell.2017.04.037.

31. Dube D, Brecher MB, Delos SE, Rose SC, Park EW, Schornberg KL, Kuhn JH, White JM. 2009. The primed ebolavirus glycoprotein (19-kilodalton GP1,2): sequence and residues critical for host cell binding. J Virol 83:2883-2891. https://doi.org/10.1128/JVI.01956-08.

32. Lennemann NJ, Rhein BA, Ndungo E, Chandran K, Qiu X, Maury W. 2014. Comprehensive functional analysis of $\mathrm{N}$-linked glycans on Ebola virus GP1. mBio 5:e00862-13. https://doi.org/10.1128/mBio.00862-13.

33. Bale S, Liu T, Li S, Wang Y, Abelson D, Fusco M, Woods VL, Saphire EO. 2011. Ebola virus glycoprotein needs an additional trigger, beyond proteolytic priming for membrane fusion. PLoS Negl Trop Dis 5:e1395. https://doi.org/10.1371/journal.pntd.0001395.

34. Fénéant L, Szymańska-de Wijs KM, Nelson EA, White JM. 2019. An exploration of conditions proposed to trigger the Ebola virus glycoprotein for fusion. PLoS One 14:e0219312. https://doi.org/10.1371/journal.pone.0219312.

35. Eggink D, de Taeye SW, Bontjer I, Klasse PJ, Langedijk JPM, Berkhout B, Sanders RW. 2016. HIV-1 escape from a peptidic anchor inhibitor through stabilization of the envelope glycoprotein spike. J Virol 90:10587-10599. https://doi.org/10.1128/JVI.01616-16.
36. Cotter $\mathrm{CR}$, Jin $\mathrm{H}$, Chen Z. 2014. A single amino acid in the stalk region of the H1N1pdm influenza virus HA protein affects viral fusion, stability and infectivity. PLoS Pathog 10:e1003831. https://doi.org/10.1371/journal.ppat.1003831.

37. Kurosaki Y, Ueda MT, Nakano Y, Yasuda J, Koyanagi Y, Sato K, Nakagawa S. 2018. Different effects of two mutations on the infectivity of Ebola virus glycoprotein in nine mammalian species. J Gen Virol 99:181-186. https:// doi.org/10.1099/jgv.0.000999.

38. Gregory SM, Larsson P, Nelson EA, Kasson PM, White JM, Tamm LK. 2014. Ebolavirus entry requires a compact hydrophobic fist at the tip of the fusion loop. J Virol 88:6636-6649. https://doi.org/10.1128/JVI.00396-14.

39. DuBois RM, Zaraket H, Reddivari M, Heath RJ, White SW, Russell CJ. 2011. Acid stability of the hemagglutinin protein regulates $\mathrm{H} 5 \mathrm{~N} 1$ influenza virus pathogenicity. PLoS Pathog 7:e1002398. https://doi.org/10.1371/journal .ppat.1002398.

40. Bouvin-Pley M, Beretta M, Moreau A, Roch E, Essat A, Goujard C, Chaix ML, Moiré N, Martin L, Meyer L, Barin F, Braibant M. 2019. Evolution of the envelope glycoprotein of HIV-1 clade B toward higher infectious properties over the course of the epidemic. J Virol 93:e01171-18. https://doi.org/ 10.1128/JVI.01171-18.

41. Gerlach T, Hensen L, Matrosovich T, Bergmann J, Winkler M, Peteranderl C, Klenk H-D, Weber F, Herold S, Pöhlmann S, Matrosovich M. 2017. pH optimum of hemagglutinin-mediated membrane fusion determines sensitivity of influenza A viruses to the interferon-induced antiviral state and IFITMs. J Virol 91:e00246-17. https://doi.org/10.1128/JVI.00246-17.

42. Takada A, Robison C, Goto H, Sanchez A, Murti KG, Whitt MA, Kawaoka Y. 1997. A system for functional analysis of Ebola virus glycoprotein. Proc Natl Acad Sci U S A 94:14764-14769. https://doi.org/10.1073/pnas.94.26 .14764.

43. Jeffers SA, Sanders DA, Sanchez A. 2002. Covalent modifications of the Ebola virus glycoprotein. J Virol 76:12463-12472. https://doi.org/10.1128/ jvi.76.24.12463-12472.2002.

44. Lee JE, Fusco ML, Hessell AJ, Oswald WB, Burton DR, Saphire EO. 2008. Structure of the Ebola virus glycoprotein bound to an antibody from a human survivor. Nature 454:177-182. https://doi.org/10.1038/nature07082.

45. Bornholdt ZA, Ndungo E, Fusco ML, Bale S, Flyak Al, Crowe JE, Jr, Chandran K, Saphire EO. 2016. Host-primed Ebola virus GP exposes a hydrophobic NPC1 receptor-binding pocket, revealing a target for broadly neutralizing antibodies. mBio 7:e02154-15. https://doi.org/10.1128/mBio.02154-15. 